\title{
MODERASI AYAT-AYAT HIJAB DALAM PENAFSIRAN MUHAMMAD HUSAIN THABATHABAI
}

\author{
Nurul Khair \\ Universitas Internasional Ahlul Bait Teheran \\ nurulkhair97@gmail.com \\ Yopi Yana \\ Sekolah Tinggi Agama Islam Sadra Jakarta \\ nurulkhair97@gmail.com \\ Siti Hadaynayah Salsabila \\ Sekolah Tinggi Agama Islam Sadra Jakarta \\ nurulkhair97@gmail.com
}

\begin{abstract}
Abstrak
Tulisan ini merupakan telaah pustaka pemikiran Muhammad Husain Thathabai mengenai moderasi ayat-ayat hijab yang dikaji melalui salah satu magnumopusnya berjudul Tafsīr al-Mīzān. Dengan menggunakan metode deskriptif-analitis, dihasilkan kesimpulan bahwa moderasi hijab merupakan salah satu metode yang digunakan oleh Muhammad Husain Thathabai untuk mengetahui eksistensi dan esensi penerapan hijab. Kehadiran moderasi hijab sebagai metode dilatabelakangi oleh ragam perbedaan antara kaum feminis Muslim yang berpendapat hijab berasal dari peradaban masyarakat klasik diterapkan untuk mengangkat moral dan martabat setiap individu. Sedangkan, para mufasir memandang hijab berasal dari hukum syariat berdasarkan teks-teks suci Alquran bertujuan untuk melindungi keberadaan kaum Muslimah dan mendekatkan dirinya kepada-Nya. Demi mengatasi ragam perdebatan mengenai kedudukan hijab, Muhammad Husain Thathabai menafsirkan ayat-ayat hijab melalui 2 pendekatan, yaitu analisis teks dan mukāsyafah. Pendekatan analisis teks bertujuan untuk mengetahui eksistensi hijab. Sedangkan, pendekatan mukāsyafah bertujuan memperoleh esensi hijab. Dengan demikian, dapat dipahami bahwa pendekatan analisis teks dan mukāsyafah dalam moderasi tafsir Muhammad Husain Thabathabai berusaha memperoleh esensi dan eksistensi hijab untuk menengahi ragam perdebatan antara para mufasir dan feminis Muslim. Hasil dari tulisan ini, ialah menawarkan cara pandangan baru mengenai wacana dan kedudukan hijab dalam peradaban ilmu pengetahuan.
\end{abstract}

Kata Kunci: Moderasi; Hijab; Tek; Mukāsyafah; Esensi

\begin{abstract}
This paper is a literature review of Muhammad Husain Thathabai's thoughts on the moderation of hijab verses which are studied through one of his magnumopus entitled Tafsīr al-Mīzān. By using the descriptive-analytical method, the conclusion is that hijab moderation is one of the methods used by Muhammad Husain Thathabai to determine the existence and essence of the application of the hijab. The presence of hijab moderation as a method is motivated by various differences between Muslim feminists who argue that the hijab comes from classical civilization and is applied to elevate the morals and dignity of each individual. Meanwhile, the commentators view
\end{abstract}


that the hijab comes from sharia law based on the holy texts of the Qur'an which aims to protect the existence of Muslim women and draw themselves closer to Him. In order to overcome the various debates regarding the position of the hijab, Muhammad Husain Thathabai interprets the hijab verses through 2 approaches, namely text analysis and mukāsyafah. The text analysis approach aims to determine the existence of the hijab. Meanwhile, the mukāsyafah approach aims to obtain the essence of the hijab. Thus, it can be understood that the text analysis and mukāsyafah approach in moderating the interpretation of Muhammad Husain Thabathabai seeks to obtain the essence and existence of the hijab to mediate various debates between Muslim commentators and feminists. The result of this paper, is to offer a new perspective on the discourse and position of the hijab in the civilization of science.

Keywords: Moderation; Hijab; Text; Mukāsyafah; Essence

\section{Pendahuluan}

Al-quran merupakan kitab pedoman Islam yang diturunkan Allah Swt. kepada Muhmmad saw, melalui perantara Jibril untuk membimbing umat Muslim meningkatkan ketakwaan kepada-Nya melalui berbagai perintah dan larangan, seperti etika berpakaian, kewajiban menutup aurat, dan atura-aturan moralitas tentang baik dan buruk dalam berperilaku di realitas (Taufik Abdullah, 2005, h. 187). Dalam etika berpakaian, Islam senantiasa mengarahkan para penganutnya untuk menjaga tata krama berhias dan bertakwa sebagai dua identitas yang tidak bisa dipisahkan dalam kontruksi sosial dan agama, sebagaimana firman-Nya yang berbunyi:

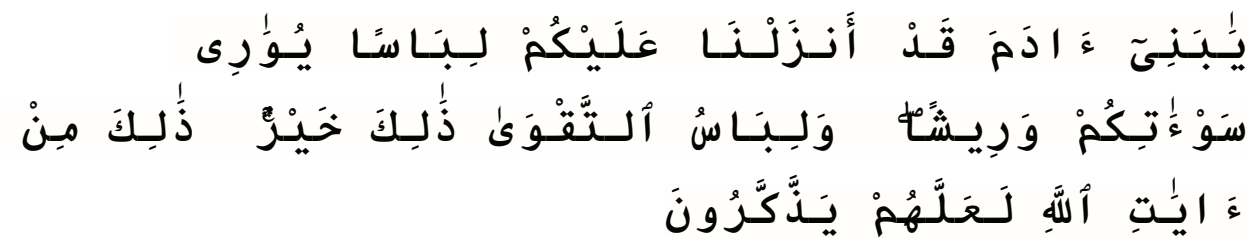

"Hai anak-anak Adam, sesungguhnya Kami telah menurunkan kepadamu pakaian untuk menutupi aurtatmu dan pakaian indah untuk perhiasan. Dan pakai takwa itulah yang paling baik. Yang demikian itu adalah sebahagian dari tanda-tanda kekuasaan Allah, memudahkan mereka selalu ingat" (Kementerian Agama Republik Indonesia, 2013, h. 153).

Berdasarkan penjelasan ayat di atas, para mufasir dan pemikir Muslim memiliki ragam pandangan memaknai problem etika berpakaian sebagai salah satu perintah yang berasal dari hukum syariat, seperti Al-Qurtubi menyebutkan keharusan umat Muslim untuk memperhatikan tata cara berpakaian yang dimulai dengan bagian tertentu atau seluruh tubuh yang dipandang sebagai aurat (Al-Qurţûbī, 2008, h. 583). Pandangan AlQurtubi dipertegas oleh Murtadha Muthhari yang menjelaskan perintah etika berpakaian 
tidak sebatas membatasi ruang-ruang tubuh atau materi individu, namun tata krama pakaian berusaha membatasi nafsu manusia yang dinilai dapat menciptakan perbuatan buruk. Pandangan Murtadha Mutahhari mengindikasikan bahwa tata krama berpakaian memiliki 2 urgensi, yaitu menutupi aurat materi dan membatasi aurat immateri, nafsu, yang dinilai sebagai indikator perilaku buruk manusia di realitas (Murtadha Mutahhari, 2000 h. 13). Murtadha Mutahhari mempertegas Qs. Al-A'raf [7]: 26 melalui QS. an-Nur [24]: 31 yang berbunyi:

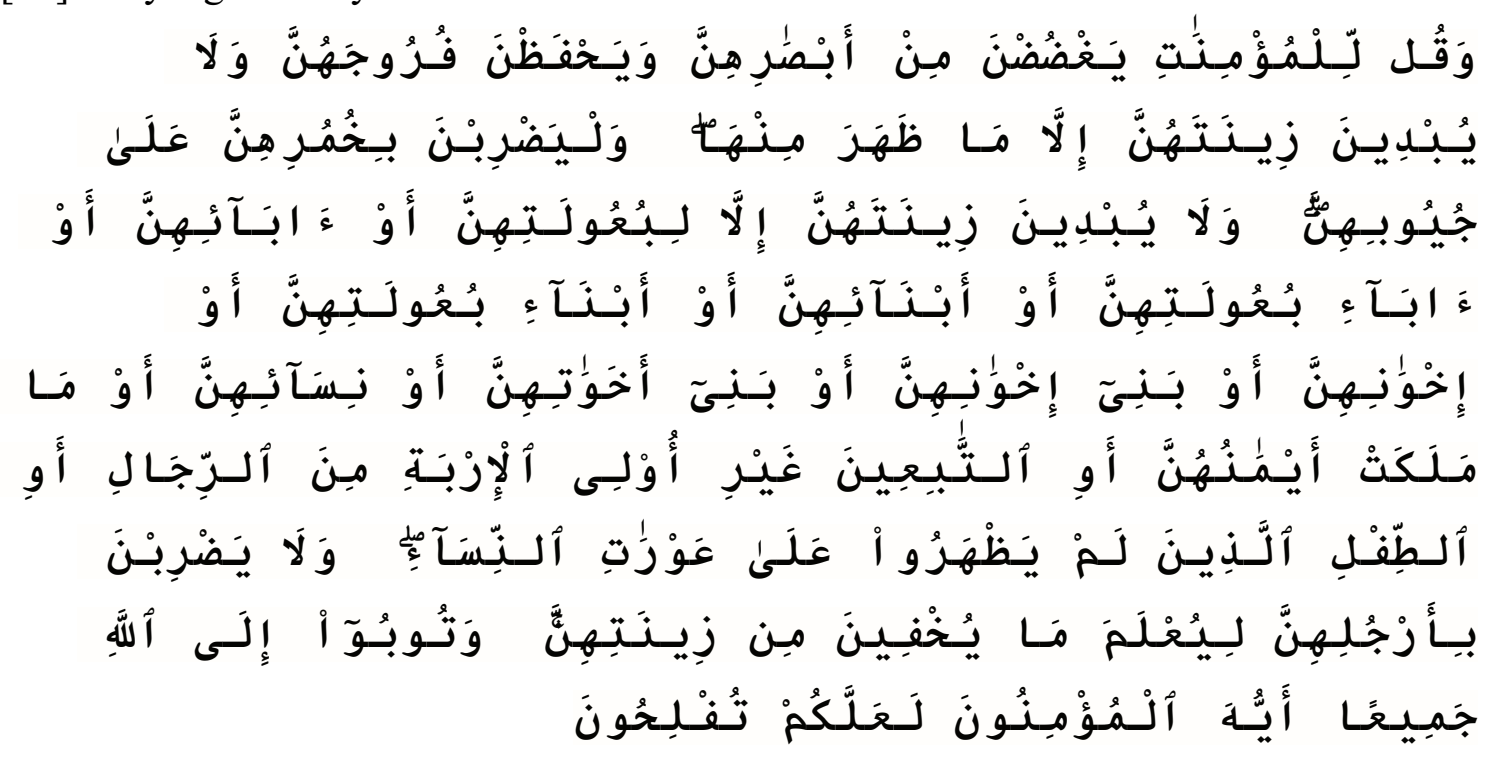

"Katakanlah kepada wanita yang beriman: Hendaklah mereka menahan pandangannya, dan memelihara kemaluannya, dan janganlah mereka menampakkan perhiasannya, kecuali yang (biasa) nampak dari padanya. Dan hendaklah mereka menutupkan kain kudung ke dadanya, dan janganlah menampakkan perhiasannya, kecuali kepada suami mereka, atau ayah mereka, atau ayah suami mereka, atau putraputra mereka, atau putra-putra suami mereka, atau saudarasaudara laki-laki mereka, atau putra-putra saudara laki-laki mereka, atau putra-putra saudara perempuan mereka, atau wanita-wanita Islam, atau budak-budak yang mereka miliki, atau pelayan-pelayan lakilaki yang tidak mempunyai keinginan (terhadap wanita) atau anak-anak yang belum mengerti tentang aurat wanita. Dan janganlah mereka memukulkan kakinya agar diketahui perhiasan yang mereka sembunyikan. Dan bertobatlah kamu sekalian kepada Allah, hai orang-orang yang beriman supaya kamu beruntung" (Kementerian Agama Republik Indonesia, 2013, h. 353).

Lebih lanjut, Murtadha Muthahhari dalam salah satu magnumopusnya berjudul “On Islamic Hijab” memandang QS. an-Nur [24]: 31 merupakan perintah yang 
diberikan Allah swt. kepada umat Muslim untuk mengetahui berbagai batasan hijab yang tujuannya membatasi pandangan individu. Batasan hijab meliputi sesuatu yang telah terlihat bagi perempuan, seperti telapak tangan dan wajahnya. Pandangan Murtadha Mutahhari selaras dengan penjelasan Ibn Abbas dan Qatadah yang mengungkapkan batasan hijab, ialah seluruh tubuh manusia, kecuali wajah dan kedua telapak tanganya (Al-Qurţûbī, 2006, h. 152). Quraish Shihab dalam salah satu karyanya berjudul “Wawasan Quran: Tafsir Maudhu'i atas pelbagai persoalan” menjelaskan berbagai perdebatan para mufasir memahami potongan QS. an-Nur [24]: 31 yang berbunyi illâmâ zhahara minhâ (kecuali apa yang nampak darinya (perhiasan). Menurut Quraish Shihab, sebagian para mufasir memandang sesuatu yang dikecualikan telah disebutkan sebelumnya, seperti perhiasan yang terlihat sebagaimana mestinya. Sedangkan, sebagian para mufasir memandang bahwa Alquran merupakan kitab universal tidak menjelaskan batasan tata cara berpakaian, sehingga manusia berusaha menafsirkan dan memahami setiap pesan universal (M. Quraish Shihab, 2003, h. 178), sebagaimana diketahui melalui Qs. al-Ahzab [33]: 59 yang berbunyi:

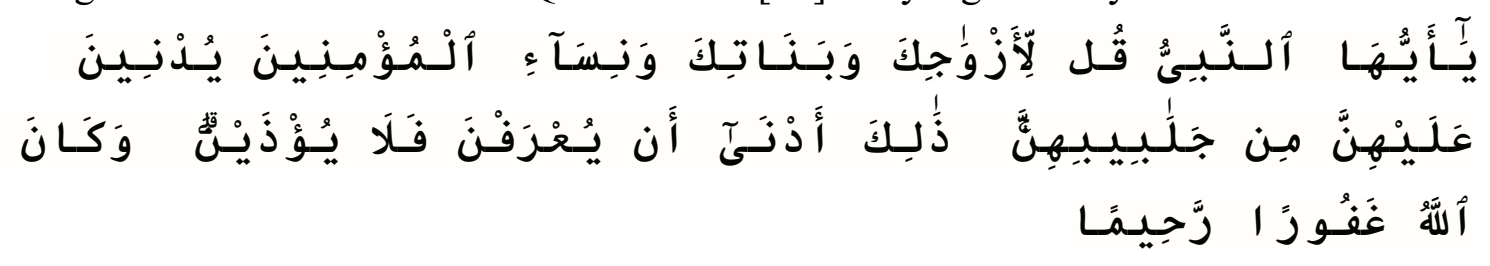

"Hai Nabi, Katakanlah kepada istri-istrimu, anak-anak perempuanmu dan istriistri orang-orang mukmin: "Hendakhlah, mereka mengulurkan jilbabnya ke seluruh tubuh mereka". Yang demikian, itu supaya mereka lebih mudah untuk dikenal, karena itu mereka tidak diganggu. Dan Allah adalah Maha Pengampun lagi Maha Penyayang” (Kementerian Agama Republik Indonesia, 2013, h. 158)

Sedangkan, sebagian para pemikir Muslim memandang tata krama berpakaian merupakan produk budaya masyarakat klasik yang telah dipraktikkan hingga hari ini, seperti Fedwa El Guidi dalam "Jilbab antara Kesalehan, Kesopanan, dan Perlawanan" memandang hijab merupakan produk budaya masyarakat klasik untuk meningkatkan moralitas kepada umat Manusia (Fadwa El Guindi, 2005, h. 47). Pandangan Fedwa El Guidi dipertegas oleh Laela Ahmed melalui pendekatan sejarah bahwa hijab merupakan salah satu bentuk kesopanan berpakaian yang telah ada 3000 SM di masa Bilalama. Kemudian berkembang di masa Asyyira, sekitar 1.500 SM, memandang hijab sebagai simbol kehormatan bagi seluruh wanita bangsawan Persia. Sedangkan menurut 
Navabakhsh, dikutip melalui Nasruddin Umar, menjelaskan hijab merupakan tradisi untuk meningkatkan derajat dan kemuliaan wanita yang ditandai dengan pelarangan para pelacur untuk menggunakan penutup kepala. Sedangkan, wanita bangsawan dan suci diharuskan untuk menutup tubuh merupakan untuk mendeskripsikan keagungannya (Nasruddin Umar, 1996, h. 39).

Berdasarkan ragam penjelasan di atas, dapat diketahui bahwa para pemikir Muslim berbeda pandangan memahami kedudukan hijab sebagai tata krama berpakaian. Demi mengatasi ragam perdebatan para pemikir Muslim, Muhammad Husain Thabathabai dalam salah satu magnumopusnya berjudul Tafsīr al-Mīzān menafsirkan ayat-ayat hijab melalui pendekatan moderasi yang bertujuan untuk memperoleh esensi dan eksistensi hijab dengan melibatkan 2 pendekatan, yaitu analisis teks dan mukāsyafah (Quraish Shihab, 2013, h. 378). Analisis teks bertujuan untuk memahami pesan tekstual yang terdapat dalam Alquran, sedangkan pendekatan mukāsyafah untuk memahami hakikat atau esensi ayat-ayat hijab yang termaktub dalam Alquran. Demi memperjelas ragam penafsiran ayat-ayat hijab, Muhammad Husain Thabathabai menjelaskan penafsiran potongan surat al-Ahzab [33]: 59 dengan memperhatikan kata jalabib merupakan jamak dari jilbab, yaitu pakaian yang menutupi seluruh tubuh atau kain yang menutupi kepala wanita. Sedangkan kata yudnīn ditafsirkan sikap mengulurkan jilbab sampai ke dada. Adapun lafaz zalika adna an yu 'rafina merupakan identitas keagungan dan kehormatan wanita. Di satu sisi, Muhammad Husain Thabathabai menegaskan hijab sebagai simbol wanita merdeka untuk melepaskan eksistensi wanita dari berbagai perbuatan tercelah yang merugikan dirinyadi realitas (Muhammad Husain Thabathabai, 1417H, h. 3). Tulisan berjudul Moderasi Ayat-Ayat Hijab dalam Penafsiran Muhammad Husain Thabathabai ini, berusaha mengkaji dan menelaah corak Tafsīr al-Mīzān sebagai salah satu magnumopus Muhammad Husain Thabathabai untuk memperoleh esensi dan eksistensi hijab dalam paradigma para pemikir Muslim yang dikembangkan melalui beberapa sub pembahasan, antara lain; pendekatan moderasi, diskursus makna hijab, hijab antara hukum syariat atau budaya, penyajian ayat-ayat hijab, dan tafsir hijab dalam pandangan Muhammad Husain Thabathabai.

\section{Metode Penelitian}


Penelitian ini merupakan penelitian kepustakaan (library research) yang bertujuan melakukan pencarian dan penelaan terhadap data atau informasi mengenai moderasi tafsir hijab Muhammad Husain Thabathabai, baik dari buku, kitab tafsir, jurnal ilmu tafsir, skripsi, tesis, dan disertasi (Nurul Khair, 2020, h. 33-34). Dalam mencari dan menelaah data penelitian, penulis menggunakan metode tematik tokoh yang bersifat deskriptif-analitis. Metode tematik tokoh adalah pendekatan yang membahas pandangan, ide, dan gagasan seorang tokoh mengenai satu tema atau istilah dalam Alquran (Ahmad Tanzeh, 2011, h. 48). Penelitian ini membahas pandangan Muhammad Husain Thabathabai mengenai penafsiran ayat-ayat hijab yang dikaji melalui pendekatan moderasi untuk memperoleh esensi dan hakikat hijab dalam Alquran. Dalam membahas dan mengkaji moderasi tafsir hijab perspektif Muhammad Husain Thabathabai, penulis mengumpulkan data penelitian melalui dua sumber, yaitu primer dan sekunder (Kaelan, 2017, h. 62-63). Sumber primer yang dirujuk dari Tafsīr al-Mīzān dengan menyoroti moderasi tafsir hijab Muhammad Husain Thabathabai. Sedangkan sumber sekunder dalam penelitian ini, ialah merujuk pada buku, jurnal, skripsi, tesis, dan disertasi yang membahas pemikiran, dan tafsir Muhammad Husain Thabathabai.

Data-data yang diperoleh melalui sumber primer dan sekunder dikumpulkan menjadi satu, kemudian diklasifikasi berdasarkan subtema dalam penelitian ini untuk menghasilkan sebuah kajian dan pembahasan komprehensif yang dideskripsikan secara sistematis dalam penelitian ini (Conny R. Semiawan, 2010 h. 10). Data-data yang dikumpulkan dan dideskripsikan, selanjutnya dianalisis untuk memahami urgensi moderasi tafsir hijab Muhammad Husain Thabathabai sebagai solusi terhadap ragam perdebatan para pemikir Muslim mengenai etika berpakaian dalam Alquran (Moh. Nazir, 2005, h. 54). Di satu sisi, analisis terhadap data primer dan sekunder juga bertujuan untuk menjelaskan signifikansi tafsir Muhammad Husain Thabathabai dalam menyingkap esensi dan eksistensi hijab.

\section{Hasil dan Pembahasan}

\section{Pendekatan Moderasi}

Secara etimologi kata moderasi berasal dari bahasa Inggris, yaitu moderation bermakna sesuatu yang bersifat tengah-tengah dari dua eksistensi yang berlawanan (AS 
Horby, 2000, hal. 855). Dalam bahasa Arab, kata moderation memiliki makna yang sama dengan kata الوسطية (al-wasathiyah), ialah sesuatu yang memiliki kedudukan tengah-tengah dari dua eksistensi yang berbeda (M. Quraish Shihab, 2007, h.1035). Pemaknaan dalam bahasa Inggris dan Arab menginformasikan bahwa kata moderasi memiliki makna identik dengan kata moderat. Dalam Kamus Besar Bahasa Indonesia (KBBI), kata moderat ialah kecenderungan ke arah dimensi yang seimbang (1), selalu menghindarkan perilaku atau pengungkapan yang ekstrim, cenderung ke arah dimensi atau jalan tengah, dapat mempertimbangkan pandangan pihak lain (2) (Pusat Bahasa Dep. Pendidikan Nasional, 2005, h. 751). Ibnu 'Asyur dalam kitabnya berjudul 'Asyur at-Tahri wa at-Tanwir menjelaskan makna moderasi ialah tengah-tengah dari dua batas yang berbeda antara satu sama lain (Muhammad Ibn Asyur at-Thahir, 1984, h. 7). Pandangan Ibn 'Asyur memiliki keidentikan dengan pandangan Khaled Abou el Fadl dalam bukunya berjudul Great Theft menjelaskan moderasi ialah paham mengambil jalan tengah dari dua jalan yang bersebrangan atau bertentangan (Khaled Abou el Fadl, 2008, h. 30).

Pandangan Khaled Abou el Fadl mendeskripsikan bahwa sikap moderasi merupakan penengah terhadap dua jalan yang berbeda satu sama lainnya. Adapun, menurut Ibn Faris, dikutip melalui Agus Zaenal Fitri, menjelaskan bahwa moderasi atau menunjukkan posisi adil tanpa memihak dari dua kondisi yang berlawanan (Agus Zaenal Fitri, 2015, h. 46). Ibn Faris menghubungkan definisinya dengan kata امة وسطا Qs. al-Baqarah [2]:143, bermakna umat berada di tengah-tengah. Makna umat yang berada di tengah-tengah dalam pandangan Ibn Faris ialah sikap adil yang harus ditunjukan oleh umat Muslim selama berada di dunia, sebagaimana perintah Allah SWT. Dari berbagai pandangan para pemikir Muslim, dapat disimpulkan bahwa moderasi ialah kecenderungan untuk memilih sikap tengah terhadap dua dimensi atau jalan yang berbeda antara satu sama lain. Posisi tengah antara dua dimensi berbeda mendeskripsikan sikap adil individu untuk merespon suatu objek. Dalam penelitian ilmiah, pendekatan moderasi merupakan suatu sikap tengah-tengah untuk membuktikan kebenaran objek kajian tanpa mengutamakan salah satu dari dua perkara yang ditelaah. Dengan demikian, dapat dipahami bahwa pendekatan moderasi bertujuan untuk memperoleh esensi dan eksistensi suatu objek tanpa mengutamakan suatu paradigma 
atau terlepas dari pola pikir ekstrem yang senantiasa menyalahkan pandangan di luar keyakinannya.

Dalam tulisan ini, peneliti berusaha mengkaji kedudukan hijab sebagai objek kajian melalui pendekatan moderasi yang bertujuan mengetahui kedudukan hijab sebagai tema serius dalam diskursus ilmu pengetahuan. Dalam diskurus konsep hijab, diketahui ada dua aliran yang memiliki pandangan berbeda. Pandangan pertama, mayoritas kaum feminis seperti Fedwa El Guindi menjelaskan bahwa hijab merupakan produk budaya masyarakat klasik untuk memberikan nilai moral kepada para wanita (Fadwa El-Guindi, 2005, h. 47-48). Sedangkan pandangan kedua, para mufasir memandang bahwa hijab merupakan syariat agama yang harus dipraktikan oleh setiap Muslimah untuk meningkatkan ketakwaanya (Dadi Ahmadi dan Nova Yohana, 2007, h. 236: Lihat juga M. Quraish Shihab, 2014, h. 52). Ragam pandangan yang berbeda mengenai kedudukan hijab didasari oleh persepktif yang digunakan oleh para pemikir, baik feminisme maupun agama. Kaum feminis menggunakan pendekatan sejarah untuk membuktikan bahwa hijab berasal dari budaya masyarakat di masa lalu. Sedangkan, para mufasir menggunakan pendekatan tekstualis untuk membuktikan hijab merupakan syariat dalam Islam (Gatot Sukendor, 2016, h. 242). Pendekatan berbeda mengakibatkan pandangan individu mengalami perbedaan praktik hijab dalam kehidupannya. Individu yang memandang hijab sebagai budaya mengatakan bahwa penggunaan hijab bukanlah suatu kewajiban, melainkan sebagai kesopanan dalam konteks sosial. Sedangkan, individu memandang praktik hijab merupakan suatu kewajiban akan memandang dari aspek keimanan, sehingga individu yang tidak menggunakan hijab dipandang terlepas dari jalan-Nya (Arif Nuh Safri, 2014, h. 21). Akibatnya, setiap individu akan terjadi konflik pendapat untuk membenarkan pandangannya tanpa menelaah secara komprehensif dan mendalam. Demi mengatasi ragam permasalahan, penulis akan mengkaji makna dan kedudukan hijab sebagai budaya atau hukum syariat melalui pendekatan moderasi untuk menunjukan sikap tengah-tengah penulis antara feminis dan para mufasir.

\section{Diskursus Makna Hijab}

Secara etimologi kata hijab berasal dari bahasa Arab, yaitu hajaba bermakna alsitr atau tabir sebagai pemisah, pembatas, dan penutup sesuatu (Wardah Nuroniyah, 2017, h. 266). Gibb dan Kramers dalam salah satu karyanya yang berjudul "Shorter 
Encylopedia Of Islam" menjelaskan hijab merupakan sesuatu berfungsi untuk memisahkan dan menutupi dua hal di realitas (H.A.R Gibb dan J.H. Kramers, 1999, h. 138). Sedangkan Cyril Glass memaknai kata hijab, ialah tirai atau kain penutup (Cyril Glass, 1999, h. 133). Adapun dalam perspektif terminilogis, hijab adalah sesuatu yang menghalangi antara dua pihak hingga yang satu tidak terlihat (Cyril Glass, 1999, h. 134). Artinya, hijab merupakan etika berpakaian yang membatasi dan menutupi wanita dari pandangan lawan jenis. Alquran menjelaskan istilah hijab dalam beberapa ayat, antara lain; Qs. Al-A'raf [7]: 46, Qs. Al-Isra [17]: 45, Qs. Maryam [19]: 17, Qs. AlAhzab [33]: 53, Qs. Sad [38]: 32, Qs. Fussilat [41]: 5, Qs. Asy-Syura [42]: 51, Qs. AlMutaffifin [83]: 15. Setiap ayat Alquran menjelaskan konsep hijab secara berbeda-beda dengan memperhatikan asbabun atau penyebab turunnya ayat-ayat tersebut, seperti Qs. al-A'raf [7]: 46 menggunakan istilah hijab untuk membatasi para pendudukan surga dan neraka. Dengan demikian, dapat dipahami bahwa Qs. al-A'raf [7]: 46 membahas hijab melalui wacana eskatologi (Depag RI, 1990, h. 425).

Lebih lanjut, Qs. Al-Isra [17]: 45 juga menjelaskan hijab melalui problematika teologis yang dipandang sebagai tabir atau penutup hati kaum musyrik yang menafikan keberadaan hari akhir (Abu Ja'far Muhammad Bin Jarir bin Yazid Bin Katsir, 1978, h. 9). Adapun hijab dalam Qs. Maryam [19]: 17 dimaknai sebagai al-satir atau dinding pemisah antara Maryam dan masyarakat (Abu Ja'far Muhammad Bin Jarir bin Yazid Bin Katsir, 1978, h. 46). Sedangkan hijab dalam Qs. Al-Ahzab [33]: 53 membahas tata cara berpakaian kepada umat Muslim dengan menampilkan nilai kesopanan untuk menutupi diri dari lawan jenis yang dipandang sebagai cara menyucikan hati umat Muslim (Abu Ja'far Muhammad Bin Jarir bin Yazid Bin Katsir, 1978, h. 35). Qs. Sad [38]: 32 menjelaskan peristiwa Nabi Sulaiman as. yang terpisah barang-barang yang disukainya, akibat kelalainannya terhadap Allah Swt (Mustofa al-Maraghi, 1974, h. 217). Sedangkan, kata hijab dalam Qs. Fussilat [41]: 5 menjelaskan pemisah antara ajaran-Nya yang dibawa oleh Rasulullah Saw. dan keyakinan kaum Quraisy yang mempercayai politeistik yang berseberangan dengan konsep monoteistik (Abu Ja'far Muhammad Bin Jarir bin Yazid Bin Katsir, 1978, h. 92). Dalam Qs. Asy-Syura [42]: 51, hijab dipahami sebagai pembatas antara eksistensi Allah Swt. sebagai Pencipta dan manusia sebagai makhluk atau hamba-Nya (Abu Ja'far Muhammad Bin Jarir bin Yazid Bin Katsir, 1978, h. 28). Adapun, Qs. Al-Mutaffifin [83]: 15 menjelaskan hijab sebagai 
penghalang orang-orang munafik untuk melihat tanda-tanda kebesaran Allah Swt (Abu Ja'far Muhammad Bin Jarir bin Yazid Bin Katsir, 1978, h. 92).

Dari berbagai ragam pemaknaan di atas, dapat disimpulkan bahwa hijab merupakan pembatas, penutup, dan pemisah antara sesuatu dengan sesuatu yang lain. Dalam konteks etika berpakaian, diketahui hijab ialah pembatas antara wanita dan lawan jenis untuk menutupi pandangan yang dinilai dapat merugikan kehormatan kaum Muslimah. Abu Syuqaqah dalam bukunya berjudul "Busana dan Perhiasan Wanita Menurut Alquran dan Hadis" menjelaskan hijab sebagai etika dan kesopanan berpakaian membatasi perilaku dan pandangan seluruh hamba-Nya. Artinya, hijab juga bertujuan untuk menutupi pandangan kaum Muslimah kepada kaum Muslim, demi menghindari perilaku yang menyimpang di realitas (Abd al-Halim Mahmud Abu Syuqqah, 1998 h. 19). Dengan demikian, dapat dipahami Alquran sebagai kitab pedoman seluruh umat Muslim memaknai hijab sebagai etika dan kesopnan berpakaian untuk membatasi perilaku dan pandangan para pengikut agama Muhammad Saw. dengan tujuan meningkatkan dan mengagungkan kehormatan dan martabat hamba-Nya. Namun perlu diketahui bahwa sebagian para pemikir memandang hijab tidak berasal dari hukum agama, melainkan telah hadir dalam peradaban masyarakat klasik. AlMunajjed, seorang sosiolog dari George Washington University, memandang hijab merupakan produk masyarakat Tiongkok klasik (abad kedua sebelum Masehi) dengan memperhatikan pembatasan aktivitas antara pria dan wanita sebagai salah satu cara menghindari perbuatan buruk antara wanita dan pria di realitas. Adapun dalam kebudayaan Bizantium, para wanita diwajibkan memakai pakaian sopan dan tertib untuk menghindari ancaman kaum pria yang dinilai senantiasa menjatuhkan martabat dan keagungan kaum hawa (Rosdiana A. Bakar, 2016, h. 131). Demi memperjelas ragam pembahasan di atas, penulis akan membahas kedudukan hijab sebagai budaya atau hukum syariat pada sub-tema selanjutnya.

\section{Hijab sebagai Budaya atau Hukum Syariat}

Dalam diskursus kajian Hijab, para pemikir terbagi dua pandangan menyikapi eksistensi dan esensi etika berpakaian, yaitu kaum feminis dan para mufasir. Fadwa El Guindi dan Leila Ahmed memandang hijab merupakan kebudayaan masyarakat klasik untuk meningkatkan nilai moral dan eksistensi perempuan, seperti budaya Mesir kuno mempraktikan hijab untuk membatasi paradigma seksual kaum lelaki terhadap 
perempuan (Fadwa El Guindi, 2005, 47). Pembatasan paradigma seksual bertujuan untuk meningkatkan eksistensi perempuan yang dipandang selalu mengalami pelecehan seksual dalam kehidupan sosial. Kebudayaan Mesir kuno selaras dengan budaya masyarakat Bizantium yang memandang hijab sebagai tata cara perempuan menggunakan pakaian secara formal untuk menghindari berbagai tindakan yang merugikan eksistensinya. Pemahaman berpakaian secara berformal menggambarkan etika berbusana yang harus ditampilkan oleh setiap perempuan untuk menjelaskan keberadaannya sebagai sesuatu yang mulia di dunia (Anisa Safitri, 2017, h. 3).

Leila Ahmed dalam bukunya berjudul Women and Gender in Islam menjelaskan bahwa paradigma patriarki telah mempengaruhi tindakan dan kehendak kaum lelaki untuk mengeksploitas keberadaan perempuan di realitas (Laela Ahmed, 1992, h. 6). Dasar utama perkembangan patriarki dalam kehidupan masyarakat dahulu, baik Mesir kuno maupun bizantium didasari oleh pemahaman mereka memandang perempuan sebagai simbol rendah di dunia (Laela Ahmed, 1992, h. 7). Demi menyikapi kesalahan berpikir, praktik hijab diterapkan untuk meningkatkan kemuliaan dan eksistensi perempuan di dunia. Pandangan Laela Ahmed identik dengan pandangan Fadwa El Guidi yang menilai praktik pelecehan seksual dan rendahnya etika berpakaian merupakan sesuatu yang melatarbelakangi pemakaian hijab dalam peradaban budaya masyarakat klasik (Fadwa El Guindi, 2005, 50-51). Fedwa El Guidi memandang bahwa pemakaian hijab sebuah aturan yang harus diterapkan bagi setiap individu untuk menyadari keberadaannya sebagai entitas mulai di realitas (Anisa Safitri, 2017, h. 6).

Tradisi berhijab dalam kehidupan masyarakat klasik dipandang sebagai budaya sakral yang senantiasa dipraktikkan bagi setiap kalangan wanita. Menurut Geertz, hijab dalam pandangan masyarakat klasik merupakan suatu keyakinan dan pegang hidup yang mempengaruhi kehormatan dan keagungan perempuan. Akibatnya, kedudukan hijab dalam kacamata sejarah merupakan bagian dari great tradition (Clifford Geertz, 1992, h. 5). Implikasinya, diketahui bahwa hijab atau etika berpakaian yang dipraktikan oleh masyarakat klasik memiliki peran dan urgensi untuk membahasakan pesan-pesan sosial dan moralitas di realitas. Dengan demikian, dapat dipahami hijab menurut para pemikir tidak sebatas simbol religious, sebagaimana yang diproyeksikan oleh para mufasir. Akan tetapi, hijab dalam perspektif sejarah dipahami sebagai simbol perlawanan, perjuangan, dan kedudukan perempuan yang terbingkai sebagai identitas budaya, 
sehingga para wanita dari masa klasik hingga sekarang akan terus mempraktikan hijab yang diartikan keagungan dan kehormatan eksistensinya (Jawadi Amuli, 2005, h. 66).

Berdasarkan ragam penjelasan di atas, dapat disimpulkan hijab dalam pandangan kaum feminis merupakan simbol perlawanan, perjuangan, dan kedudukan eksistensi perempuan dalam konstruksi sosial. Akibatnya, hijab dinilai sebagai sebuah keyakinan dan pegangan hidup yang harus dipraktikan untuk mendeskripsikan keagungan dan kehormatan kaum wanita di realitas. Pandangan kaum feminis tidak selaras dengan pemahaman para mufasir, seperti AlQurţûbī, Ibn Jubair, Ibn 'Athiyah, dan Murtadha Muthahhari memandang hijab merupakan produk ilahi yang disampaikan oleh manusia sempurna kepada para pengikutnya untuk meraih kesucian dan ketakwaan kepada Sang Ilahi (Al-Qurtubi, 2008, h. 583). Proses kesucian dan ketakwaan telah diatur hukum syariat melalui praktik hijab untuk mengarahkan perilaku dan tindakan individu. Akan tetapi, perlu digarisbawahi bahwa para ulama memiliki ragam pandang menyikapi konsep hijab yang diatur oleh hukum syariat. Al-Qurtubi dalam magnumopusnya yang berjudul Al-Jami' li Ahkam Al-Qur'an memaknai hijab, ialah pakaian longgar yang menutupi seluruh tubuh (Al-Qurtubi, 2006 h. 152). Hijab sebagai penutup tubuh perempuan dalam pandangan Al-Qurtubi bertujuan untuk menghilangkan pandanganpandangan seksualitas yang merendahkan eksistensi perempuan di realitas. Al-Qurtubi mempertegas pandangannya dengan menampilkan beberapa pandangan ulama lain, seperti Ibn Jubair mengartikan hijab, ialah sesuatu yang menutupi diri para wanita, kecuali bagian wajahnya yang terlihat (Al-Qurtubi, 2006 h. 152).

Penjelasan Ibn Jubair dipertegas oleh Ibn 'Athiyah melalui pengutipan AlQurtubi bahwa penutupan diri perempuan juga berlaku pada kedua telapak tangannya (Al-Qurtubi, 2006 h. 152). Al-Qurtubi menyetujui pandangan Ibn 'Athiyah bahwa hijab merupakan pakaian yang berfungsi untuk menutupi eksistensi perempuan dari berbagai perbuatan tercelah. Ragam pandangan para mufasir, khususnya Al-Qurtubi, Ibn Jubair, dan Ibn 'Athiyah mengenai makna hijab didasari QS. an-Nur [24]: 31 yang berbunyi:

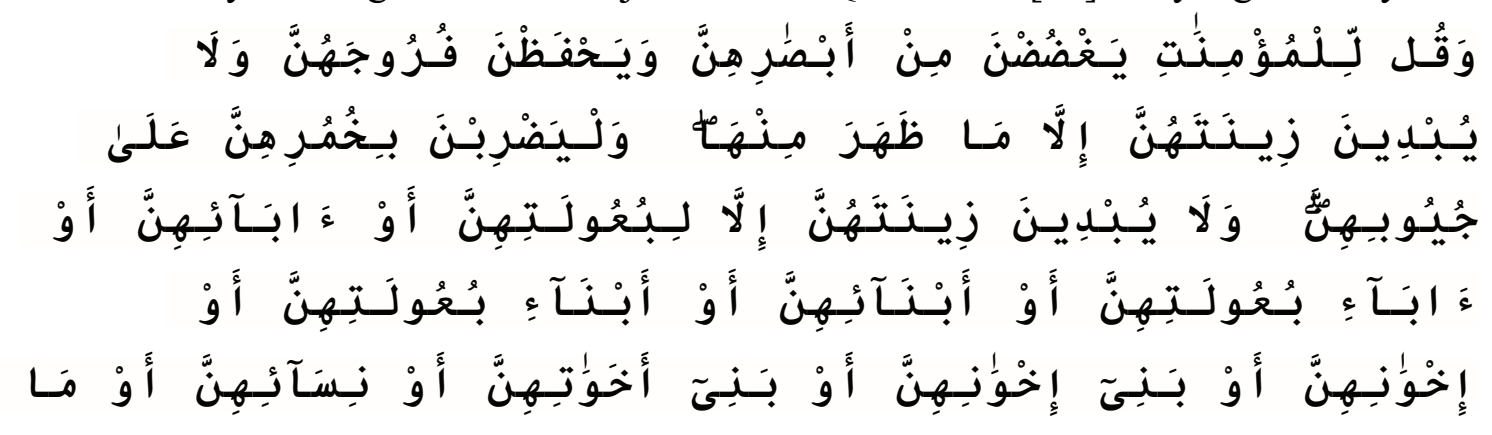




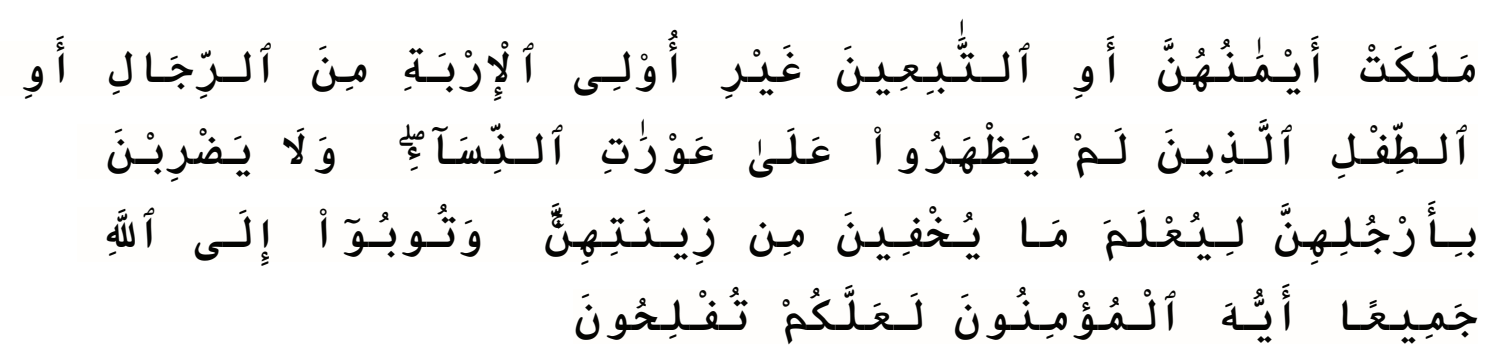

"Katakanlah kepada wanita yang beriman: Hendaklah mereka menahan pandangannya, dan memelihara kemaluannya, dan janganlah mereka menampakkan perhiasannya, kecuali yang (biasa) nampak dari padanya. Dan hendaklah mereka menutupkan kain kudung ke dadanya, dan janganlah menampakkan perhiasannya, kecuali kepada suami mereka, atau ayah mereka, atau ayah suami mereka, atau putraputra mereka, atau putra-putra suami mereka, atau saudarasaudara laki-laki mereka, atau putra-putra saudara laki-laki mereka, atau putra-putra saudara perempuan mereka, atau wanita-wanita Islam, atau budak-budak yang mereka miliki, atau pelayan-pelayan lakilaki yang tidak mempunyai keinginan (terhadap wanita) atau anak-anak yang belum mengerti tentang aurat wanita. Dan janganlah mereka memukulkan kakinya agar diketahui perhiasan yang mereka sembunyikan. Dan bertobatlah kamu sekalian kepada Allah, hai orang-orang yang beriman supaya kamu beruntung" (Kementerian Agama Republik Indonesia, 2013, h. 535).

Menurut Al-Qurţûbī, Ibn Jubair, dan Ibn 'Athiyah QS. an-Nur [24]: 31 menjelaskan kewajiban kaum Muslimah untuk menjaga pandangan dan memelihara kemaluannya dari berbagai kehidupan di dunia. Cara utama bagi wanita untuk menjaga pandangan dan memelihara tubuh melalui praktik hijab yang menutupi seluruh tubuhnya, sehingga wanita dan pria dapat menghindari tindak seksualitas. Hilangnya tindakan seksualitas mencerminkan eksistensi perempuan terhindar dari berbagai sikap yang merugikan dirinya di realitas (Thoha Husain, 2010, h. 153). Di satu sisi, praktik hijab merupakan respon umat Muslim terhadap ragam penindasan kaum perempuan sebelum Islam yang memandang perempuan sebagai keberadaan skunder yang seharusnya memenuhi hasrat dan harapan kaum lelaki melalui bentuk tubuh yang mengundang perilaku seksualitas. Paradigma eksistensi berdasarkan tubuh dan perilaku seksualitas yang menimpa perempuan menggambarkan hilangnya kemuliaan dalam diri wanita di tengah masyarakat (Arvind Sharma, 1994, h. 305). Islam dipandang sebagai agama rahmatan lil alamin berusaha mengangkat kembali eksistensi wanita sebagai 
individu yang mulia dan sempurna melalui praktik hijab yang dikategorikan sebagai hukum syariat.

Berdasarkan ragam penjelasan para mufasir, dapat diketahui bahwa hijab sebagai hukum syariat berusaha menjaga kesucian dan kemuliaan wanita dari berbagai tindakan yang merugikan eksistensinya di realitas (Al-Thahir al-Hadad, 1992, h. 10). Pada dasarnya, hijab dalam pandangan budaya dan hukum syariat memiliki tujan yang sama, yaitu derajat eksistensi perempuan di dunia. Penerapan hijab sebagai budaya persepktif kaum feminis dilatarbelakangi oleh praktik patriarki yang senantiasa memanfaatkan perempuan berdasarkan arahan nafsunya (Fadwa El Guindi, 2005, 47). Hukum syariat dalam praktik hijab juga berusaha menghapus ragam tindakan seksualitas yang dipandang telah merugikan wanita dengan membatasi cara pandang kaum laki-laki sebagai nafsu paling dasar dalam kehidupan manusia di dunia (Abu Majadidul Sa'adah, 2011, h. 25). Meskipun, hijab dalam pandangan budaya dan hukum syariat memiliki tujuan yang sama, perlu diketahui bahwa hijab perspektif budaya tidak menjelaskan batasan-batasan praktik hijab dalam pakaian wanita. Akibatnya, praktik hijab mengalami perbedaan di setiap tempat dan waktu, seperti; wanita Persia dan Arab menggunakan hijab dengan memperlihatkan rambutnya di bagian depan. Sedangkan, wanita Mesir kuno menggunakan hijab dengan menutupi kepala, mulut, dan hidungnya (Fadwa El Guindi, 2005, 48-49).

Hukum syariat berusaha menyatukan ragam budaya mengenai praktik hijab dengan menjelaskan batasan-batasan aurat dalam praktik hijab. Kata aurat merupakan tema pokok dalam kajian hijab, sebab aurat merupakan objek utama yang dibatasi oleh hijab. Artinya, pembahasan hijab tidak akan hadir dalam diskursus agama tanpa keberadaan aurat (Siti Nur Khamzah, 2011, h. 30). Hukum syariat telah memberikan penjelasan secara radikal tentang aurat sebagai kontribusi bagi pengetahuan para wanita untuk menjaga pandangan dan memelihara kemualiannya dari berbagai tindakan seksualitas. Wanita yang menjaga kedua item tersebut akan mendeskripsikan kesucian, kesalehan, dan kemuliaan di dunia. Penerapan kesucian, kesalehan, dan eksistensinya akan membimbing setiap wanita untuk mendekatkan diri kepada Allah SWT. Proses kedekatan wanita sebagai hamba kepada Tuhannya merupakan salah satu kritikan agama-agama terdahulu yang memandang urusan agama diberikan kepada kaum lakilaki sebagai mahluk primer. Sedangkan, perempuan merupakan makhluk skunder yang 
tidak dapat mendekatkan diri kepada Tuhan tanpa bantuan kaum laki-laki, sebagaimana wanita-wanita Yahudi tidak diperkenankan untuk mendekatkan diri kepada Tuhan secara langsung di tempat ibadah. Peribadahan perempuan ditunjukan kepada pelayanan mereka terhadap kaum laki-laki. Akibatnya, eksistensi perempuan senantiasa dimanfaatkan dan dieksploitasi berdasarkan keinginan nafsu laki-laki (Nina Nurmila, 2015, h. 5-6). Praktik hijab berusaha memperbaiki paradigma masyarakat beragama terdahulu memandang bahwa perempuan dapat mendekatkan diri kepada Tuhan dengan cara menjaga pandangan dan kemaluannya sebagai proses kesucian, kesalehan, dan kemuliaan sehingga setiap manusia memiliki derajat eksistensi sejajar beribadah kepada-Nya tanpa memandang status bersifat aksidental, yaitu primer dan skunder (Ahmad Fauzi, 2016, h. 42).

Berdasarkan penjelasan di atas, dapat diketahui bahwa praktik hijab juga berperan untuk proses peribadahan seorang wanita kepada Tuhannya dengan menjaga pandangan mereka dari berbagai tindak yang menjatuhkan eksistensinya, sebagaimana diketahui penutupan hijab seluruh tubuh menunjukan tertutupnya aurat-aurat dalam tubuh perempuan. Meskipun, diketahui butuh penjelasan komprehensif mengenai ayatayat hijab untuk menyikapi moderasi penafsiran para mufasir dan pandangan kaum feminis. Demi menyempurnakan ragam pembahasa pada sub-tema sebelumnya, penulis akan menjelaskan penyajian ayat-ayat hijab sebagai ruang pemahaman dan pengetahuan terhadap praktik hijab sebagai etika berpakaian yang diwajibkan kepada kaum wanita, baik klasik maupun hari ini.

\section{Tafsir Moderasi Ayat-Ayat Hijab Menurut Muhammad Husain Thabathabai}

Muhammad Husain Thabathabai dalam penafsiran moderasi ayat-ayat hijab melakukan pengkajian tekstual untuk memahami esensi atau hakikat hijab dalam Alquran melalui telaah Qs. Al-Ahzab [33]: 59, QS. An-Nur [24]: 31, dan Qs. Al-A'raf [7]: 26 yang dipandang sebagai rujukan utama memahami hakikat etika berpakaian (Muhammad Husain Thabathabai, 1417H, h. 152). Muhammad Husain Thabathabai memulai penjelasan tafsir hijab sebagai etika berpakai melalui Qs. Al-Ahzab [33]: 59 yang dinilai sebagai ayat pembuka dari semua ayat-ayat pakaian. Dalam potongan Qs.

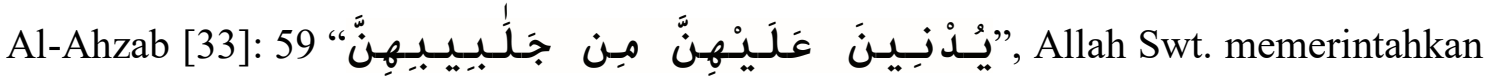
kepada Rasulullah saw. untuk meminta seluruh wanita menutupi tubuhnya dengan tujuan menghindari berbagai ragam tindak pelecehan yang merugikan keberadannya. Di 
satu sisi, diketahui bahwa Qs. Al-Ahzab [33]: 59 mendeskripsikan kasih dan sayangNya dengan menjaga umatnya dari dosa dan sesuatu yang diharamkan-Nya (Muhammad Husain Thabathabai, 1417H, h. 499).

Lebih lanjut, Muhammad Husain Thabathabai dalam Tafsir al-Mizan juga menerangkan hukum syariat berusaha menjaga kehormatan dan kesucian setiap makhluk, sehingga jika memahami Qs. Al-Ahzab [33]: 59 secara tekstual, maka diketahui kemuliaan kaum wanita dalam Alquran sebagai individu yang harus dijaga dan dilindungi di realitas (Ahmad Fauzan, 2018, h. 123: Lihat juga Ikhlas Budiman, 2015, h. 67). Adapun hijab sebagai produk budaya, sebagaimana dijelaskan oleh kaum feminis, menurut Muhammad Husain Thabathabai, hukum syariat hadir untuk mempertegas budaya masyarakat klasik tanpa mengubah dan menggantinya dengan memperhatikan kodrat dan hakikat manusia yang mulia dan terhormat Muhammad Qasim Ilyasi, 1387SH, h. 162). Muhammad Husain Thabathabai mempertegas ragam penafsiran Qs. Al-Ahzab [33]: 59 melalui interpretasinya dalam QS. An-Nur [24]: 31,

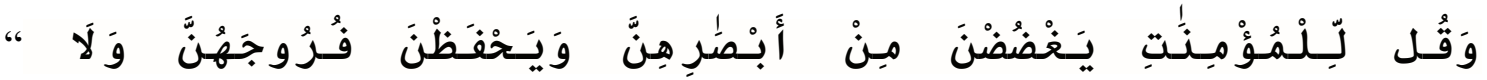
menjelaskan setiap perempuan yang beriman untuk menjaga pandangannya dan kemaluannya. Akan tetapi, Muhammad Husain Thabathabai menekankan cara pandang yang dinilai sebagai sebab utama yang menggerakan individu untuk berbuat dosa dan maksiat (Muhammad Husain Thabathabai, $1417 \mathrm{H}$, h. 155). Muhammad Husain Thabathabai selaras dengan pandangan muridnya, Murtadha Mutahhari yang memandang hijab tidak sebatas pakaian materi atau selembar kain yang menutupi tubuh wanita dengan batasan tertentu. Akan tetapi, Muhammad Husain Thabathabai memandang bahwa hijab sebagai pembatas dan penutup immateri yang menjaga hawa nafsu individu di realitas. Dengan demikian, dapat diketahui hijab memiliki dua pemaknaan dalam penafsiran Muhammad Husain Thabathabai, yaitu penutup dan pembatas tubuh wanita, “يُدْنِيـنَ عَلَـيـهِنَّ

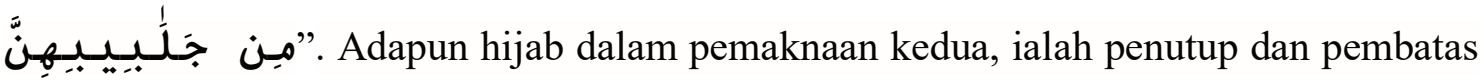
immateri yang menjaga hawa nafsu setiap individu untuk mencapai kehormatan dan kemualiannya di realitas.

Penafsiran Muhammad Husain Thabathabai selaras dengan kebudayaan Mesir dan Bizantium kuno yang mempraktikan hijab untuk menjaga kehormatan dan kemuliaan setiap wanita. Muhammad Husain Thabathabai memandang bahwa setiap 
manusia memiliki fitrah yang mendorongnya untuk bergerak dan berjuang menjaga kesucian dan harga dirinya. Hukum syariat yang termaktub dan penafsiran para mufasir berusaha untuk menjelaskan hijab sebagai bentuk kesucian dan harga diri wanita. Sedangkan, para feminis menampilkan etika berpakaian sebagai perjuangan dan perlawanan wanita terhadap hak dan kehormatannya. Dari kedua pandangan yang berbeda, Muhammad Husain Thabathabai menunjukkan pendekatan moderasi dengan memandang setiap pandangan, paradigma, dan penafsiran bersifat baik di atas fitrah manusia. Para mufasir menilai hijab sebagai bentuk kesucian, sebaliknya kaum feminis menyebut hijab sebagai bentuk perlawanan terhadap kehormatan. Keduanya selaras menjelaskan eksistensi wanita sebagai keberadaan mulia, terhormat, dan suci yang tidak dipandang sebagai eksistensi skunder dan simbol kerendahan di realitas (Sayyid Ja'far Haq Shinos, 1386SH, h. 53).

Demi mempertegas penafsiran Qs. Al-Ahzab [33]: 59 dan QS. An-Nur [24]: 31, Muhammad Husain Thabathabai menjelaskan kedudukan hijab dalam Qs. Al-A'raf [7]: 26 bahwa hijab dalam hukum syariat dan budaya merupakan pakaian beribadah dan

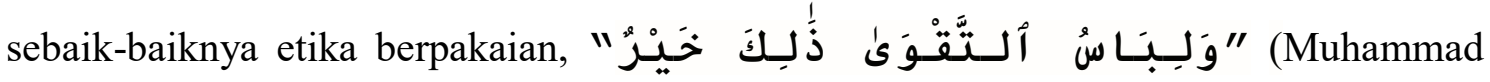
Husain Thabathabai, 1417H, h. 20). Muhammad Husain Thabathabai menjelaskan 2 argumentasi utama mengenai hijab sebagai pakaian terbaik dan takwa. Pertama, Muhammad Husain Thabathabai menafsirkan Qs. Al-Ahzab [33]: 30-32 untuk membatasi perbuatan tercelah dan meningkatkan perilaku terpuji. Allah Swt. dalam Qs. Al-Ahzab [33]: 59 telah memerintahkan praktik hijab sebagai ruang aktualitas kesucian dan kehormatannya dan menjaga pandangannya, dalam QS. An-Nur [24]: 31, untuk membatasi hawa nafsu manusia. Hijab sebagai ruang aktualitas kesucian dan kehormatan merupakan bentuk ketakwaan kaum Muslimah di hadapan wanita yang mendeskripsikan kedekatannya kepada Allah Swt (Muhammad Nasir al-Din al-Albani, 2001, h. 10) Muhammad Husain Thabathabai mempertegas penafsiran Qs. Al-Ahzab

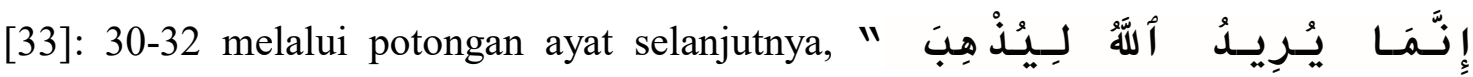
bahwa Allah Swt. ingin menyucikan wanita sebagai bentuk kasih sayang dan penjagan-Nya di realitas (Muhammad Husain Thabathabai, 1417H, h. 454).

Kedua, ayat-ayat hijab dalam pandangan Muhammad Husain Thabathabai berusaha mengarahkan manusia untuk menghindari ragam kerugiaan dalam perilaku dan perbuatannya, sebagaimana potongan Qs. Al-A'raf [7]: 23 yang berbunyi " قَّا لَ 


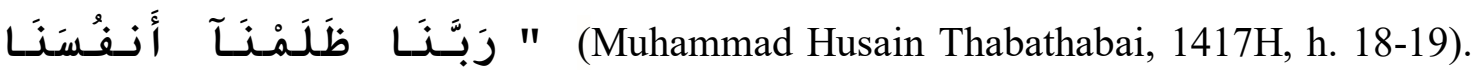

Penafsiran Qs. Al-A'raf [7]: 23 dipertegas melalui Qs. Al-A'raf [7]: 26 yang memandang hijab sebagai etika berpakaian terbaik untuk menyadarkan dan membebaskan manusia dari berbagai kerugian di realitas (Shaban Poor, 1396SH, h. 81). Berdasarkan 2 argumentasi hijab, Muhammad Husain Thabathabai mulai memaknai etika berpakaian melalui pendekatan mukāsyafah yang dipandang sebagai ruang aktualitas kedekatan kaum wanita kepada Sang Pencipta, sebagaimana bunyi Qs. Al-

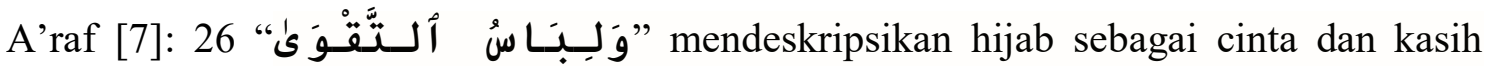
sayang-Nya kepada seluruh makhluk. Lebih lanjut, Muhammad Husain Thabathabai memandang arti kasih dan cinta Allah Swt. kepada kaum Muslimah merupakan penjagaan-Nya terhadap berbagai tindakan yang menyimpang dan dosa yang menimpah hamba-Nya. Artinya, hijab tidak sebatas dipandang sebagai tata cara berpakaian formal dalam Al-Mīzan fì Tafsīr Al-Qur'ān. Namun, hijab dipandang sebagai perlindungan Allah Swt. kepada wanita yang dipandang sebagai eksistensi yang mulia dan terhormat. Akibatnya, hijab dinilai sebagai simbol keagungan kaum Muslimah di realitas (Shaban Poor, 1396SH, h. 86).

Ragam penafsiran dan argumentasi Muhammad Husain Thabathabai bertujuan untuk menengahi dan menyelesaikan ragam perdebatan para mufasir dan kaum feminis. Secara analisis teks, hijab merupakan etika berpakaian yang menutupi dan membatasi tubuh wanita dari pandangan lawan jenis. Secara mukāsyafah, hijab ialah pakaian ketakwaan sebagai ruang aktualitas kedekatan kaum Muslimah kepada Tuhannya. Penafsiran tekstual dan mukāsyafah dalam pandangan Muhammad Husain Thabathabai mendeskripsikan eksistensi dan esensi hijab bahwa eksistensi hijab dipandang sebagai etika berpakaian untuk meningkatkan derajat, kehormatan, dan kemuliaan wanita. Sedangkan, esensi dari hijab ialah ruang penyembahan yang mendeskripsikan setiap individu memiliki kedudukan yang sejajar di hadapan-Nya tanpa memandang perbedaan gender atau jenis kelamin (Hamka, 1982, h. 171).

Berdasarkan ragam penjelasan di atas, dapat disimpulkan tafsir moderasi ayatayat hijab dalam pandangan Muhammad Husain Thabathabai berusaha menyatukan berbagai paradigma kaum feminis dan para mufasir. Secara esensi, hijab merupakan ruang penyembahan wanita untuk meraih kesucian dan kehormatannya tidak jauh berbeda dengan eksistensi hijab untuk meningkatkan derajat, kehormatan, dan 
kesuciaannya Muhammad Nasib Rifa'i, 1999, h. 488). Eksistensi dan esensi hijab yang telah ditelaah dan dikaji oleh kaum agamawaan dan feminis berusaha menempatkan wanita sebagai keberadaan yang sejajar tanpa memandang sebagai simbol kerendahan atau tertindas. Hukum syariat yang termaktub dalam Alquran berusaha menjelaskan kemuliaan wanita. Sedangkan, praktik hijab dalam budaya klasik bertujuan untuk mengembalikan kehormatan wanita yang senantiasa dieksploitasi melalui paradigma seksual (Fadwa El-Guindi, 2005, h. 47). Dari berbagai penjelasan, Muhammad Husain Thabathabai menegaskan bahwa hukum syariat dan budaya masyarakat tidak bertentangan. Hukum syariat hadir untuk mempertegas dan menyempurnakan tradisi yang dinilai selaras dengan fitrah manusia. Di satu sisi, kebudayaan berusaha mempertegas hukum syariat melalui dinamika praktik etika berpakaian di realitas. Dengan demikian, dapat dipahami bahwa tafsir moderasi ayat-ayat hijab perspektif Muhammad Husain Thatahabai telah menyatukan ragam pandangan hijab dalam diskursus etika berpakaian.

\section{Penutup}

Berdasarkan ragam penjelasan sebelumnya, dapat diketahui bahwa moderasi ayat-ayat hijab dalam penafsiran Muhammad Husain Thabathabai berusaha menengahi ragam perdebatan wacana etika berpakaian antara pandangan kaum feminis dan para mufasir. Muhammad Husain Thabathabai menilai hukum syariat yang termaktub dalam Alquran tidak mengubah budaya masyarakat klasik. Akan tetapi, hukum syariat menyempurnakan dan menegaskan tradisi yang telah dipraktikan masyarakat klasik kepada seluruh individu di realitas. Hijab dalam penafsiran Muhammad Husain Thabathabai memiliki dua kedudukan yang ditinjau melalui analisis teks dan mukāsyafah. Secara analisis teks, Muhammad Husain Thabathabai menjelaskan hijab merupakan perintah Allah Swt. kepada setiap wanita untuk menutup, membatasi, dan menghalangi tubuhnya dari berbagai pandangan lawan jenis. Sedangkan secara mukāsyafah, hijab ialah ruang aktualitas penyembahan kaum Muslimah untuk mendekatkan diri kepada Tuhannya. Penjelasan teks dan mukāsyafah dalam penafsiran Muhammad Husain Thabathabai mendeskripsikan eksistensi hijab bertujuan untuk menjaga, melindungi, dan meningkatkan kehormatan wanita dari berbagai dosa dan maksiat. Adapun secara esensi, ialah pakaian ketakwaan untuk meraih kesucian dalam ruang peribadahan kepada-Nya. 
Dalam diskursus hijab, para mufasir dan feminis memiliki pandangan selaras dengan pendekatan yang berbeda. Menurut Muhammad Husain Thabathabai, para feminis memandang hijab ialah simbol perjuangan kaum wanita atas kehormatan dan kemuliannya. Di satu sisi, para mufasir menilai hijab merupakan etika berpakaian yang diperintahkan Allah Swt. untuk mengarahkan individu merealisasikan kesucian dan keagungannya. Akan tetapi, Muhammad Husain Thabathabai dalam penafsiran ayatayat hijab menjelaskan paradigma kaum feminis dan para mufasir berusaha meningkatkan derajat dan kesucian kaum Muslimah yang sejalan dengan fitrah manusia, sehingga kedua paradigma tidak perlu diperdebatkan mengenai asal dan peran hijab dalam kehidupan masyarakat. Sebaliknya, paradigma kaum feminis dan para mufasir menurut Muhammad Husain Thabathabai saling menguatkan dan menyempurnakan satu sama lain untuk memahami dan mengetahui esensi dan kedudukan hijab di realitas. Dengan demikian, dapat disimpulkan bahwa hijab dalam penafsiran Muhammad Husain Thabathabai bertujuan untuk merealisasikan ruang kesempurnaan manusia untuk mencapai kesucian, kesempurnaan, dan kehormatannya.

\section{DAFTAR PUSTAKA}

Abdullah, Taufik. (2005). Cakrawala Ilmu dalam Al-Qur'an. Jakarta: Pustaka Firdaus. Ahmadi Dadi dan Nova Yohana. (2007). Konstruksi Jilbab sebagai Simbol Keislaman. Jurnal Mediator, 8 (2).

Ahmed, Laela. (1992). Woman and Gender in Islam. London: Yale University.

Albani, Muhammad, Nasir, al-Din, Al-. (2001). Jilbab Wanita Muslimah Menurut AlQur'an dan as-Sunnah, diterjemahkan oleh Hawin Murtadha. Solo: AtTibyan.

Alif, Naila, Rahmatika. (2012). Eksistensi Hijab Wanita Menurut Murtadha Muthahhari. Skripsi: Institut Islam Negeri Sunan Ampel.

Amuli, Jawadi. Keindahan dan Keagungan Perempuan. Jakarta: Sadra Press, 2005.

Bakar, Rosdiana, A. (2016). Hijab dan Jilbab dalam Prespektif Sejarah. Jurnal AlIrsyad, 6 (1).

Budiman, Ikhlas. (2015). Penerapan Teori-teori Filosofi dalam penafsiran al-Qur'an. Jurnal Tanzil, 1 (1).

Depag RI. Al-Qur'an dan Tafsirnya. Yogyakarta: UUI, 1990.

Fadl, Khaled, Abou, El. Great Theft: Wrestling Islam from the Extremist. New York: Herperone, 2008.

Fauzan, Ahmad. "Manhaj Tafsir Al-Mizan fi Tafsir Al-Qur'an Karya Muhammad Husain Tabatabai". Al-Tadabur: Jurnal Ilmu Alquran dan Tafsir 3 (2), 2018:123.

Fauzi, Ahmad. "Pakaian Wanita Muslimah dalam Perspektif Hukum Islam". Jurnal Iqtisodiah 1 (1), 2016: 42. 
Fitri, Agus, Zaenal. (2015). Pendidikan Islam Wasathiyah: Melawan Arus Pemikiran Takfiri di Nusantara. Jurnal Kuriositas, 8 (1).

Gibb, H.A.R dan J.H. Kramers. (1999). Shorter Encyclopedia of Islam. Netherlands: Ledin E.J. Brill.

Glass, Cyril. (1999). Ensiklopedi Islam. Jakarta: PT. Raja Grafindo Persada.

Geertz, Clifford. (1992). Kebudayaan dan Agama, diterjemahkan oleh F. Budihardiman. Yogyakarta: Kanisius.

Guindi, Fadwa El. (2005). Jilbab, Antara Kesalehan, Kesopanan Dan Perlawanan, diterjemahkan oleh Mujiburrahman. Jakarta: Serambi Ilmu Semesta.

Hadad, Al-Thahir, Al-. (1992). Wanita dalam Syari'at dan Masyarakat. Jakarta: Pustaka Firdaus.

Horby, AS. (2000). Oxford Advanced Leaner's Dictionary of Current Englsih. Oxford: Oxford University.

Husain, Thoha. Al-Qur'an dan Terjemahannya. Jakarta: Al-Huda, 2010.

Ilyasi, Muhammad, Qasim. (1387SH). "Rābt-e Syariat va Syāsat az Didgāh-e Hikmat-e Mutaliyāh". Pozuhesh Ulum-e Insani, 4 (3).

Kaelan. Metode Penelitian Alquran dan Tafsir. Yogyakarta: Idea Press, 2017.

Katsir, Abu Ja'far, Muhammad. (1978). Jami' Bayan 'An Ta 'Will Ayi Qur'an. Beirut: Dar al-Fikr.

Khair, Nurul. (2020). "Takwil As-Sirat Al-Mustaqim dalam Pembacaan Tafsir Mulla Sadra”. Quhas Journal, 9 (2).

Khamzah, Siti, Nur. (2011). Puaskan Matamu dengan Auratku. Yogjakarta: Diva Press.

Kementerian Agama Republik Indonesia. (2013). Al-Qur'an Al-Karim dan Terjemahnya. Surabaya: Halim Publishing dan Distributhing.

Maraghi, Mustofa, Al-. (1974). Tafsir al-Maraghi. Beirut: Dar al-Ihya' al-Turath alArabi.

Mawardi, Imam. (2012). Seni Studi Islam Perantara Sosial di dalam Islam. Magelang: P3SI.

Murtadha, Mutahhari. (2000). On the Islamic Hijab. Tehran: Internasional Publishing.

Nazir, Moh. (2005). Metode Penelitian. Bogor: Ghalia Indonesia.

Nurmila, Nina. (2015). Pengaruh Budaya Patriarki terhadap Pemahaman Agama dan Pembentukan Budaya. Jurnal Karsa, 23 (1).

Nuroniyah, Wardah. (2017). Deskontruksi Hijab. Jurnal Al-Manhaj, 9 (2).

Poor, Shaban. (1396 SH). Tahlili bar Hijab va A'vav az Manzur-e Qur'an ba Tikye bar Maslahat dar Nazariy-e Idrakat-e I'tibari Allamah Thabathabai. Andisy-e Allamah Thabathabai, 4 (6).

Pusat Bahasa Dep. Pendidikan Nasional. (2005). Kamus Besar Bahasa Indonesia. Jakarta: Balai Pustaka.

Qurţûbī, Al-. (2008). Tafsir Al-Qurţûbī. Jakarta: Pustaka Azzam.

----o-. (2006). Al-Jami' Li Ahkam Al-Qur'an. Beirut: Mu'assah al-Risalah.

Rifa'i, Muhammad, Nasib. (1999). Kemudahan dari Allah: Ringkasan Tafsir Ibn Katsir. Jakarta: Gema Insani Press.

Sa'adah, Abu, Majadidul. (2011). Memahami Aurat dan Wanita. Bandung: Lumbung Insani.

Safri, Arif, Nuh. (2014). Pergeseran Mitologi Hijab. Jurnal Musawa, 13 (1).

Safitri, Anisa. (2017). Jilbab dalam Pandangan Fadwa El Guindi: Telaah atas Buku "Veil: Modesty Pricacy, and Resistance. Skripsi: UIN Sunan Ampel. 
Semiawan, Conny R. (2010). Metode Penelitian Kualitatif. Jakarta: PT. Grasindo.

Shinos, Sayyid, Ja'far, Haq. (1386SH). Hijāb dar Ayāt-e Qurān ba Negahi be Rivayāt. Fasl-e Nāme Surāy-e Farhanggi Ijtimā-i Zanān, 36 (2).

Sidiq, Umar. (2012). Diskursus Makna Jilbab dalam Surat al-Ahzab Ayat 59: Menurut Ibnu Kathir dan Quraish Shihab. Jurnal Kodifikasia, 6 (1).

Sharma, Arvind. (1994). Today's Woman in The World Religions. New York: State University of New York Press.

Shihab, M. Quraish. (2003). Wawasan Al-Qur'an: Tafsir Maudhu'i atas Pelbagai Persoalan. Bandung: Mizan. Hati. . (2007). Ensiklopedi Al-Qur'an Kajian Kosakata. Jakarta; Lentera (2014). Jilbab Busana Muslimah: Pandangan Ulama Masa Lalu dan Cendikiawan Kontemporer. Tanggerang: Lentera Hati.

(2013). Kaidah Tafsir: Syarat, Kentetuan, dan Aturan yang Patuh Anda Ketahui dalam Memahami al-Qur'an. Jakarta: Lentera Hati.

Sukendor, Gatot. (2016). Nilai Fetisisme Komoditas Gaya Hijab: Kerudung dan Jilbab dalam Busana Muslimah. Jurnal Sosioteknologi, 15 (2).

Syahridawaty. (2020). Fenomena Fashio Hijab dan Niqab Perspektif Tafsir Maqāsidi. Substantia: Jurnal Ilmu-Ilmu Ushuluddin, 22 (2).

Syuqqah, Abd al-Halim, Mahmud Abu. (1998). Busana dan Perhiasan Wanita menurut Alquran dan Hadis, diterjemahkan oleh Mudzakir Abdussalam. Bandung: Mizan.

Tanzeh, Ahmad. (2011). Metode Penelitian Praktis. Yogjakarta: Penerbit Teras.

Thabathabai, Muhammad, Husain. (1417H) Al-Mizān Fi Tafsir Al-Qur'ān. Qom: Hauzah Alamiyah.

Thahir, Muhammad, Ibn Asyur, At. (1984). At-Tahrîr wa al- Tanwir. Tunis: al-Dar Tunisiyyah.

Umar, Nasarudin. (1996). “Antropologi Jilbab”. Jurnal Ulumul Qur’an, 6 (5). 